\title{
Downregulation of ACE2 induces overstimulation of the renin-angiotensin system in COVID-19: should we block the renin-angiotensin system?
}

\author{
François Silhol $^{1} \cdot$ Gabrielle Sarlon $^{1} \cdot$ Jean-Claude Deharo ${ }^{1} \cdot$ Bernard Vaïsse $^{1}$
}

Received: 4 April 2020 / Revised: 6 April 2020 / Accepted: 6 April 2020 / Published online: 22 May 2020

(C) The Japanese Society of Hypertension 2020

Severe acute respiratory syndrome coronavirus 2 is the cause of the ongoing coronavirus disease-19 (COVID-19) pandemic. Mortality is mainly due to acute respiratory distress syndrome (ARDS) [1].

High blood pressure appeared to be an independent factor for severity in patients with COVID-19 [2, 3].

The renin-angiotensin system (RAS) is a hemodynamic and biological system that regulates blood pressure, plasma potassium, and the stability of pulmonary epithelial membranes (Fig. 1) [4]. In this system, two antagonistic pathways are balanced. The first is the angiotensinogen pathway that transforms angiotensinogen into angiotensin I (by renin), and then converts it into angiotensin II by angiotensin converting enzyme (ACE). Angiotensin II attaches to angiotensin II type 1 receptor (AT1R) and activates the system to induce vasoconstriction, aldosterone secretion stimulation, hypokalemia, and pulmonary epithelium degradation [5].

The second way in which the angiotensin system is balanced involves a second angiotensin converting enzyme (ACE2) $[6,7]$. This pathway transforms a part of angiotensin I [1-10] and angiotensin II [1-8] before it attaches to its AT1R receptor. The angiotensin I and II phosphorylation products are angiotensin 1-9 and angiotensin 1-7. They attach to the angiotensin II type 2 receptor receiver, inducing antagonist effects compared with AT1R [8].

In the infection phase (Fig. 2), COVID-19 virus uses the enzymatic receptor of ACE2 to penetrate the host cell $[9,10]$. Coronavirus binding with ACE2 has been shown to lead to a downregulation of ACE2 [11], contributing to an increase in

François Silhol

francois.silhol@ap-hm.fr

1 Cardiology Department, HTA and Vascular Medicine University Hospital Timone, Marseille, France angiotensin 2 through ACE, as the decrease in ACE2 results in a lower conversion of angiotensin to angiotensin 1-7 vasodilator [12]. The lower the level of ACE2, the lesser angiotensin I [1-10] and angiotensin II [1-8] will be degraded; thus, their plasmatic concentration gradually increases. A US intensive care unit team demonstrated that an increase in angiotensin 1-10 and a decrease in angiotensin 1-9 (its ACE2 processing product) were correlated with a poor prognosis in ARDS [1].

Thus, elevations in angiotensin II concentrations and stimulation of AT1R lead to a decrease in the stability of the pulmonary endothelium and an aggravation of respiratory distress $[13,14]$. The other effects are an increased secretion of aldosterone, hypokalemia induced by kaliuresis, and increased sodium reabsorption and inflammation [15].

Hypokalemia is frequently found in patients with COVID19. A Chinese team recently reported that hypokalemia was associated with a poor outcome (Wuhan's experience) [16].

Conversely, RAS blockers can increase ACE2 and potentially promote virus loading into the cell [17].

We believe that major imbalance in RAS induced by the downregulation of ACE2 is an essential element of unfavorable evolution in patients with COVID-19. The biological marker of this imbalance appears to be hypokalemia.

Several studies in influenza and Ebola lung infections have shown the beneficial role of AT1R blockers on lung damage, with a decrease in inflammation and cytokines [18-21]. In two animal studies, losartan demonstrated an increase in ACE2 expression [22, 23].

Losartan was also the molecule chosen in two trials recently started in the United States by the University of Minnesota to treat patients with COVID-19 (clinical trials. gov NCT04311177 and NCT 104312009). We began a preliminary study to document the kinetics of RAS in COVID+ patients (SAR-COV) before therapeutic evaluation (ISRA-COV). 
Fig. 1 Renin-angiotensin system (RAS) regulation

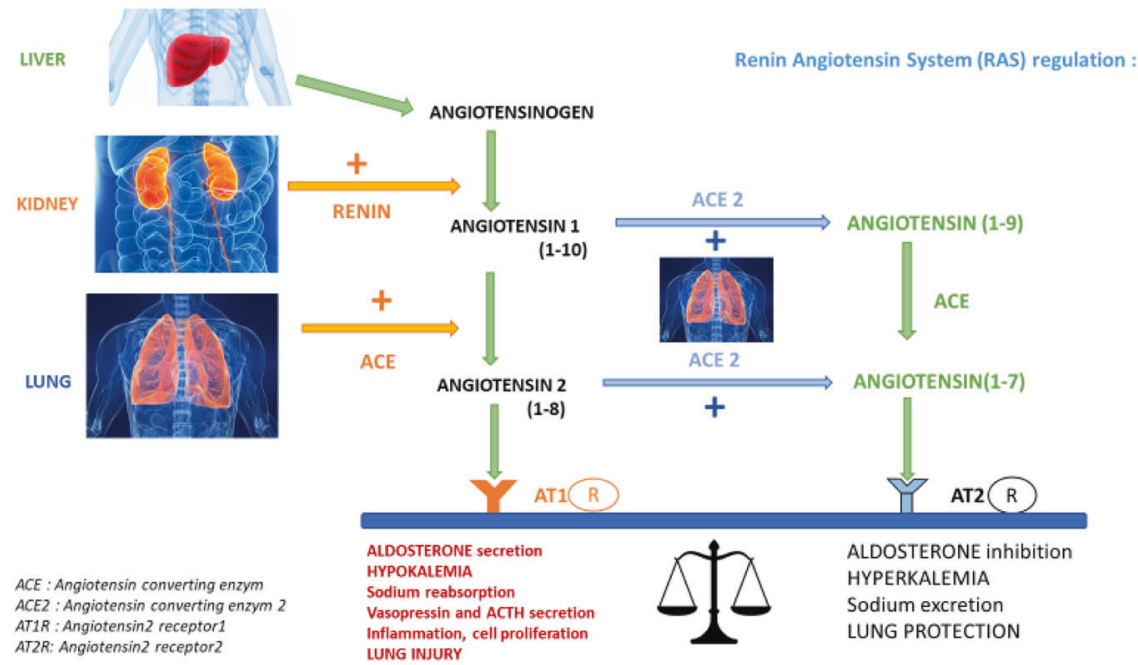

Fig. 2 Downregulation of ACE2 during COVID-19 increases AT1R stimulation, hypokalemia, and lung and cardiovascular injury (FS)

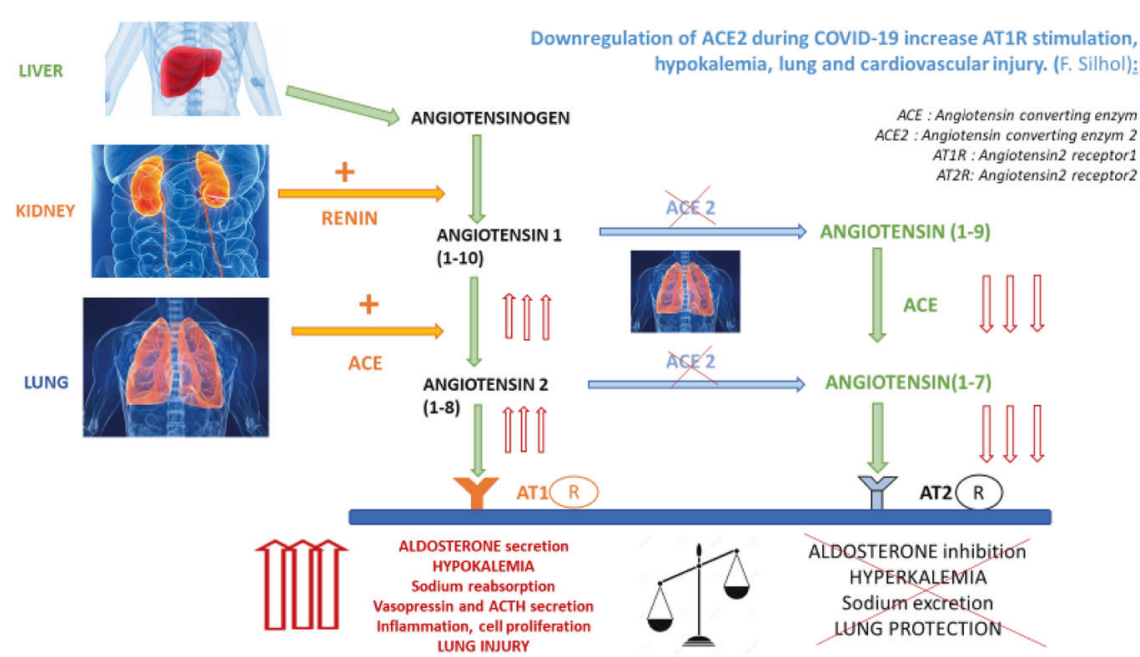

Clarification is needed to determine whether blockers of the angiotensin system have a protective or harmful effect in these patients [24]. In particular, we strongly need to evaluate how blocking the overactivation of the RAS by an AT1R blocker (such as losartan) in patients with COVID-19 could decrease respiratory decompensation and hemodynamic disorders and thus limit the number of patients with poor prognosis.

\section{Compliance with ethical standards}

Conflict of interest The authors declare that they have no conflict of interest.

Publisher's note Springer Nature remains neutral with regard to jurisdictional claims in published maps and institutional affiliations.

\section{References}

1. Reddy R, Asante I, Liu S, Parikh P, Liebler J, Borok Z, et al. Circulating angiotensin peptides levels in acute respiratory distress syndrome correlate with clinical outcomes: a pilot study. PLoS ONE. 2019. https://doi.org/10.1371/journal.pone.0213096.

2. Huang C, Wang Y, Li X, Ren L, Zhao J, Hu Y, et al. Clinical features of patients infected with 2019 novel coronavirus in Wuhan, China. Lancet. 2020;395:497-506.

3. World Health Organization. WHO Director-General's opening remarks at the media briefing on COVID-19. World Health Organization; 2020. https://www.who.int/dg/speeches/detail/whodirector-general-s-opening-remarks-at-the-media-briefing-oncovid-19-11-march-2020.

4. Bullock GR, Steyaert I, Bilbe G, Carey RM, Kips J, De Paepe B, et al. Distribution of type-1 and type- 2 angiotensin receptors in the normal human lung and in lungs from patients with chronic obstructive pulmonary disease. Histochem Cell Biol. 2001;115: 117-24.

5. Tipnis SR, Hooper NM, Hyde R, Karran E, Christie G, Turner AJ. Human homolog of angiotensin-converting enzyme. Cloning and functional expression as a captopril-insensitive carboxypeptidase. J Biol Chem. 2000;275:33238-43. https://doi.org/10.1074/jbc. M002615200.

6. Batlle D, Wysocki J, Soler MJ, Ranganath K. Angiotensinconverting enzyme 2: enhancing the degradation of angiotensin II as a potential therapy for diabetic nephropathy. Kidney Int. 2012;81:520-8. https://doi.org/10.1038/ki.2011.381. 
7. Hamming I, Timens W, Bulthuis ML, Lely AT, Navis G, Van Goor $\mathrm{H}$. Tissue distribution of ACE2 protein, the functional receptor for SARS coronavirus. A first step in understanding SARS pathogenesis. J Pathol. 2004;203:631-7. https://doi.org/10.1002/path.1570.

8. Ferrario CM, Chappell MC, Tallant EA, Brosnihan KB, Diz DI. Counterregulatory actions of angiotensin-(1-7). Hypertension. 1997;30:535-41. https://doi.org/10.1161/01.hyp.30.3.535.

9. Lu R, Zhao X, Li J, Niu P, Yang B, Wu H, et al. Genomic characterisation and epidemiology of 2019 novel coronavirus: implications for virus origins and receptor binding. Lancet. 2020. https://doi.org/10.1016/S0140-6736(20)30251-8.

10. Wan Y, Shang J, Graham R, Baric RS, Li F. Receptor recognition on by the novel coronavirus from Wuhan: an analysis based on decade-long structural studies of SARS coronavirus. J Virol. 2020;94. pii: e00127-20. https://doi.org/10.1128/JVI.00127-20.

11. Yumiko I, Kuba K, Penninger Josef M. The discovery of ACE2 role in acute lung injury in mice. Exp Physiol. 2008;93:543-8.

12. Ohshima K, Mogi M, Nakaoka H, Iwanami J, Min LJ, Kanno H, et al. Possible role of angiotensin-converting enzyme 2 and activation of angiotensin II type 2 receptor by angiotensin-(1-7) in improvement of vascular remodeling by angiotensin II type 1 receptor blockade. Hypertension. 2014;63:e53-9.

13. Imai Y, Kuba K, Rao S, Huan Y, Guo F, Leong-Poi H. Angiotensinconverting enzyme 2 protects from severe acute lung failure. Nature. 2005;436:112-6. https://doi.org/10.1038/nature03712.

14. Kuba K, Imai Y, Penninger JM. A crucial role of angiotensin converting enzyme 2 (ACE2) in SARS coronavirus-induced lung injury. Nat Med. 2005;11:875-9.

15. Lijnen P, Petrov V, Fagard R. Induction of cardiac fibrosis by angiotensin II. Methods Find Exp Clin Pharmacol. 2000;22:709-24. https://doi.org/10.1358/mf.2000.22.10.

16. D Chen, $X$ Zhang. Hypokalemia and clinical implications in patients with coronavirus disease 2019 (COVID-19). Preprint at https://doi.org/10.1101/2020.02.27.20028530.
17. Diaz JH. Hypothesis: angiotensine converting enzyme inhibitor and angiotensine receptor blocker may increase the risk of severe Covid19. J Travel Med. 2020; pii: taaa041. https://doi.org/10. 1093/jtm/taaa041.

18. Hagiwara S, Iwasaka H, Hidaka S, Hasegawa A, Koga H, Noguchi T. Antagonist of the type-1 ANG II receptor prevents against LPS-induced septic shock in rats. Intensive Care Med. 2009; 35:1471-8

19. Iwai M, Nakaoka H, Senba I, Kanno H, Moritani T, Horiuchi M. Possible involvement of angiotensin-converting enzyme 2 and Mas activation in inhibitory effects of angiotensin II Type 1 receptor blockade on vascular remodeling. Hypertension. 2012;60:137-44.

20. Wong MH, Chapin OC, Johnson MD. LPS-stimulated cytokine production in type I cells is modulated by the renin-angiotensin system. Am J Respir Cell Mol Biol. 2012;46:641-50.

21. Clancy P, Koblar SA, Golledge J. Angiotensin receptor 1 blockade reduces secretion of inflammation associated cytokines from cultured human carotid atheroma and vascular cells in association with reduced extracellular signal regulated kinase expression and activation. Atherosclerosis. 2014;236:108-15.

22. Ishiyama Y, Gallagher PE, Averill DB, Tallant EA, Brosnihan $\mathrm{KB}$, Ferrario CM. Upregulation of angiotensin-converting enzyme 2 after myocardial infarction by blockade of angiotensin II receptors. Hypertension. 2004;43:970-6.

23. Klimas J, Olvedy M, Ochodnicka-Mackovicova K, Kruzliak P, Cacanyiova S, Kristek F, et al. Perinatally administered losartan augments renal ACE2 expression but not cardiac or renal Mas receptor in spontaneously hypertensive rats. J Cell Mol Med. 2015;19:1965-74. https://doi.org/10.1111/jcmm.12573.

24. Danser AHJ, Epstein M, Batlle D. Renin-Angiotensin system blockers and the COVID-19 pandemic at present there is no evidence to abandon Renin-Angiotensin system blockers. Hypertension. Preprint at https://www.ahajournals.org/journal/hyp https://doi. org/10.1161/HYPERTENSIONAHA.120.15082 (2020). 